\title{
Use of Digital Games in Teaching Vocabulary to Young Learners
}

Esin Hazar 


\title{
Use of Digital Games in Teaching Vocabulary to Young Learners
}

\author{
Esin Hazar ${ }^{a^{*}}$ \\ ${ }^{a}$ Cumhuriyet University, Faculty of Education, Department of Educational Sciences, 58140 Merkez/Sivas, Turkey \\ *Corresponding author: hazaresin@cumhuriyet.edu.tr
}

\section{Abstract}

\section{Keywords:}

Digital games; English; vocabulary; young learners

\section{Schlüsselworte:}

Digitale Spiele;

Englisch; Wortschatz; junge Lerner

\section{Zusammenfasung}

It has been an educational policy for the Turkish educational authorities to teach English as a foreign language from early ages of children. This research attempts to determine the role of digital games on enhancing English vocabulary and to com-pare games with pen and paper practices. For this purpose, digital games on EBA (Education Informatics Network) platform were used for enhancing vocabulary teaching in a public primary school in Turkey. The study recruited 37 third-grade students from two separate classes. A class of 20 students was identified as the experimental group, and another class of 17 students was assigned as the control group. The data for this study was obtained by gathering information from pre and post-tests. The control group received English lessons without using games on EBA, while the experimental group used EBA while learning vocabulary. Independent sample t-test was used to measure the effect of digital games on the vocabulary learning of the experimental group. It was deduced from the findings that there were statistically significant differences in the mean scores of post-tests. The findings showed that the experimental group outperformed the control group and the statistical results were considerable in post-test. Findings indicate that digital games usage in teaching vocabulary is effective for learners to improve their vocabulary knowledge.
(1)

r die Türkischen Bildungsbehörden war es eine Bildungspolitik, Englisch als Fremdsprache von klein auf zu unterrichten. Diese Forschung versucht, die Rolle digitaler Spiele bei der Verbesserung des englischen Wortschatzes zu bestimmen und Spiele mit Stift- und Papierpraktiken zu vergleichen. Zu diesem Zweck wurden digitale Spiele auf der EBA-Plattform (Education Informatics Network) verwendet, um den Wortschatzunterricht in einer öffentlichen Grundschule in der Türkei zu verbessern. Die Studie rekrutierte 37 Schüler der dritten Klasse aus zwei getrennten Klassen. Eine Klasse von 20 Schülern wurde als Versuchsgruppe identifiziert, und eine weitere Klasse von 17 Schülern wurde als Kontrollgruppe zugewiesen. Die Daten für diese Studie wurden durch Sammeln von Informationen aus Vor- und Nachuntersuchungen erhalten. Die Kontrollgruppe erhielt Englischunterricht ohne Verwendung von EBA-Spielen, während die Versuchsgruppe EBA beim Erlernen des Wortschatzes verwendete. Ein unabhängiger Stichproben-T-Test wurde verwendet, um die Auswirkung digitaler Spiele auf das Vokabellernen der Versuchsgruppe zu messen. Aus den Ergebnissen wurde abgeleitet, dass es statistisch signifikante Unterschiede in den Durchschnittswerten der Nachuntersuchungen gab. Die Ergebnisse zeigten, dass die Versuchsgruppe die Kontrollgruppe übertraf und die statistischen Ergebnisse nach dem Test beträchtlich waren. Die Ergebnisse zeigen, dass die Verwendung digitaler Spiele im Vokabeltraining für Lernende effektiv ist, um ihr Vokabularwissen zu verbessern.

\section{Introduction}

Technology has a leading role in every aspect of life and education takes its part utilizing technology for teaching learning process. Educational practices are constantly seeking innovation as a result of developments in information communication technologies and changes in educational practices naturally change teaching and learning approaches.Traditionally, students have access to information through books and lectures, however, technology especially internet, which is being used in many schools, enables learning anywhere and anytime, and information is always available for students and teachers.
Together with the other subjects, foreign language teaching takes its part in using technology in classes. Different language teaching methods are applied to increase the effectiveness of teaching process and technology succeeds in replacing traditional teaching. With the spread and development of English around the world, English has long been had its place in the Turkish educational system and enjoys his status by its position as a key subject in both primary and secondary schools' curricula. Technology offers many options to make teaching interesting and at the same time make teaching 
more productive especially when in a country with little or no opportunity to encounter with a native speaker and practise the language learned. As students from early ages begin learning English, in order to attract their attention, using multimedia is a good way to satisfy both visual and auditory senses of students. In language teaching, technology such as internet, mobile phones, computers or videos offers many opportunities. Using multimedia in English language teaching has many advantages.

The aim of the foreign language teaching is to enable the students to acquire four language skills, speaking, listening, reading and writing. However, students need vocabulary to communicate using the target language. The lack of vocabularies has hindrances and obstacles for the students to speak fluently and accurately. Without vocabulary acquisition, it is impossible to construct meaningful sentences in communication (Patahuddin, Syawal \& Bin-Tahir, 2017). It is an undeniable fact that language skills require a lot of vocabulary and vocabulary helps you to express your opinion fully. Vocabulary allows the use of structures and functions that facilitate communication (Nunan, 1991). As teaching English starts at the age of 8 in the Turkish education system and young learners get distracted too soon, an effective way to teach vocabulary is the use of digital games as games are motivating and more appealing for students to learn a foreign language.

There are some studies confirming the effects of digital games on vocabulary learning (Reinhardt \& Sykes, 2014; Shyamlee \& Phil, 2012; Sundqvist \&Sylvèn, 2014; Takeuchi \& Vaala, 2014;Taghizadeh, Vaezi \& Ravan, 2017; Vasileiadou \& Makrina, 2017). However, most of them are conceptual studies and there is little empirical evidence of the impact of digital gaming in classrooms. Most digital game-based language learning research has been conducted outside the classroom but little research has been done on the integration of digital games into English classes (Thomas, 2012). To fill this gap, this study explored the implementation of digital games in English classes in a primary school. In this context, some digital platforms are investigated as there are many platforms for teachers to utilize games in their classes. One of these is $E B A$ (Education Informatics Network) which is a platform designed to be used by both teachers and students online and offline at school or out of school. By means of $E B A$, teachers can upload and download multimedia contents and use them for educational purposes. Although there are other platforms to play digital games in classes, EBA is precontrolled by the Turkish Ministry of Education and is an easy-to-use and intuitive tool that promotes motivation and competitiveness. Therefore, this research is aimed at using digital games on EBA to teach vocabulary.

In this study, it was aimed to find a solution for students' vocabulary problems. The purpose of the study is to explore the effects of digital games for overcoming students' vocabulary problems.

\section{Literature Review}

\subsection{Teaching Vocabulary}

Vocabulary is one component of language skills such as reading, speaking, listening and writing. Vocabulary knowledge enables language use, language use enables the increase of vocabulary knowledge, and knowledge of the word enables the increase of vocabulary knowledge and language use and so on. In English as Foreign Language (EFL) learning, vocabulary items play a vital role in the acquisition of the four language skills -listening, speaking, reading, and writing (Nation, 2013). Without vocabulary knowledge, neither language production nor language comprehension would be possible. Therefore, the increase of vocabulary is one of the prerequisites for language acquisition and the increase of vocabulary is only possible when teachers use effective vocabulary teaching and learning strategies (Mukoroli, 2011). Teachers should help students learn the basic steps and how to access and acquire, recognize and remember, and activate and generate new word meanings to maximize vocabulary development (Loucky, 1998).

In English classes various communicative activities can be helpful in teaching vocabulary however, the most effective way to attract attention could be met via listening or visual representation.Nowadays, there is an increasing interest towards using technology in different fields of human life, particularly in education. Digital games are used for entertainment and facilitating the process of learning (Ilomaki \& Kankaanranta, 2009).

\subsection{Digital Games}

"A game can be defined as a goal-oriented, rule-based, playful activity" (McGonigal, 2013). For today's generation, digital games play a significant role. Digital games are games that are programmed with various technologies and enable users to enter a visual environment (Çetin, 2013). Two types of games can be distinguished in this context: special purpose games developed with an educational purpose and Commercial-Off-The-Shelf games developed for entertainment purposes (Stewart et al., 2013). The launch of digital gaming in education focuses on games that are designed to teach academic content and skills to students playing them (Mayer, 2015). Hong, Cheng, Hwang, Lee and Chang (2009) classified digital games into 5 categories: (1) drill and practise games; (2) single combat games; (3) stable contest games; (4) evolutionary contest games; and (5) contextual games. 
Using drill and practise games developed with educational purpose in classrooms impacts on the mode of learning as games motivate players to achieve goals, gratify the ego when winning, is fun through enjoyment and pleasure and spark the players' creativity to solve the game (Prensky, 2001). The use of digital games as a learning tool and game-like formats could be more effective at capturing learners' attention than traditional media such as textbooks (Wood, 2001).

Teaching vocabulary through the use of games is beneficial as games provide enjoyment and interest in learning (Bakhsh, 2016). Students especially young learners accept new foreign languages easily, if effective tools are devised to teach vocabulary. Vocabulary learning is considered as a difficult task because of memorizing unfamiliar words and spelling. In order to motivate and engage students more in the learning process, games could be an effective way. Technologies used in classrooms push us to move forward from conventional pen-and-paper instruction to more interactive and productive digital classroom activities. For Liu and Chen (2013), games with animated graphics and impacts of audio provide a good motivation for vocabulary learning.

Studies carried out with young learners of English as a foreign language show that using digital games during classes has a positive impact in the acquisition of vocabulary. A study carried out by Peterson (2013) resulted that kindergarten children who were taught vocabulary using digital games achieved more compared to the children learned through regular curriculum. Sundqvist and Sylvèn (2014) pointed out that $4^{\text {th }}$ grade English learners had better outcomes in learning vocabulary than the students having been taught by traditional methods.According to Taghizadeh Vaezi and Ravan (2017), the use of games enables children to learn vocabulary better than using traditional methods. Also, Ashraf, Motlagh and Salami (2014) stressed the effect of using games in learning the vocabulary for children. Similarly, a study performed by Calvo-Ferrer (2017) showed that students used computer games scored significantly better than the ones who used other means of practicing vocabulary. In a meta-analysis of 17 studies by Yudintseva (2015) results concluded that foreign language vocabulary is enhanced when learners engage in playing video games.

Technology enhanced activities have long been in progress in Turkish education and interactive whiteboards, e books, interactive applications and internet use make a notable difference in teaching learning process. These developments create potentials for utilizing digital game activities for English classes.

Based on the aspects summarized in the introduction and literature review, the research question to be addressed is 'How effective is the use of digital games to enhance vocabulary?'

\section{Methodology}

\subsection{Research design}

The study followed a pre-test-post-test experimentalcontrol group design to know how far digital games to improve the students' vocabulary. Both the control and experimental group attended the English classes for 80 minutes per week. The former followed the regular curriculum while the latter was supported with digital game-based learning activities.

\subsection{Participants}

The participating school was a public primary school in Turkey. Two third-grade classes were randomly selected to participate in this study. The total number of participants were 37 students (18 boys and 19 girls), ranging in age from 8 years to 9 years $(M=8$ years and 5 months $)$. The experimental group $(N=20)$ included 7 girls and 13 boys, and the control group $(N=12)$ involved 5 boys and 12 girls.

\subsection{Instruments}

A pre-test including 30 vocabulary items with a maximum score of 30 was administered to the groups of the study to discover the participants' level of knowledge of English vocabulary. The instrument prepared as the pre-test included the outcomes defined by the Turkish Ministry of Education.

A post-test was carried out to measure the students' level of improvement in comparison with the results taken in the pre-test. This instrument included 30 questions that were graded out of 30 points.

\subsection{Procedure}

The data for this study were gathered for a period of 4 months in 2019- 2020 academic year. An experimental design was used in order to carry out this research. The use of digital games and its effect on learning vocabulary in the English classroom were tested. The groups of students for this study were selected according to the class they were enrolled. There were 2 groups, 1 received English classes that included activities with digital games on $E B A$ and the other taking regular classes and both studied vocabulary related to numbers, family members, adjectives, feelings, toys and games. During the study, the teacher taught the regular curriculum using the textbook, audio recordings, worksheets, tracing, cut and paste activities in both classes. For the experimental group, teacher designed classes using digital games on EBA including listening, matching and memorizing, finding and colouring activities. Digital game integration was implemented only in the experimental class.

At the beginning of the 4-month intervention period, a pre-test was administered to 37 students. At the end of the intervention, a post-test was administered to all of the participants. 
After gathering and organizing the data from pre-tests, and post-tests, SPSS software was used in the analysis of the results; thus, descriptive and inferential statistics (with a confidence level of $95 \%$ ) were applied, and the results of pre- and post-tests from the experimental and control groups, were compared and contrasted.

\section{Results}

The results of the pre-test administered to both groups to identify previous knowledge about vocabulary show that the experimental group obtained an average of 5,05 points and the control group 7,52 points. Thus, we can observe that, before the intervention, there was no significant difference $(t=1,748, p=, 08)$ between these two groups in relation to their proficiency level in EFL vocabulary.

Table 1. Descriptive statistics for pre-test scores of the groups

\begin{tabular}{llllll}
\hline & Groups & N & Mean & $\begin{array}{l}\text { Std. } \\
\text { Deviation }\end{array}$ & $\begin{array}{l}\text { Std. } \\
\text { Mean }\end{array}$ \\
\hline $\begin{array}{l}\text { Pre- } \\
\text { test }\end{array}$ & Control & 17 & 7,5294 & 4,92592 & 1,19471 \\
\cline { 2 - 5 } & Experiment & 20 & 5,0500 & 3,69174 &, 82550 \\
\hline
\end{tabular}

As regards the post-test administered to both groups, the results show that students in the experimental group increased their score $(t=-2,134, p=, 04)$. These results (see Table 2) make it evident that the use of digital games helped the students in the experimental group to increase their EFL vocabulary knowledge. This means that use of digital games was an effective tool to enhance vocabulary in these students. With respect to the control group, the increase in the post-test scores might be attributed to the regular teaching process that English teachers followed as part of the primary school curriculum.

Table 2. Descriptive statistics for post-test scores of the groups

\begin{tabular}{|c|c|c|c|c|c|}
\hline & Groups & & Mean & $\begin{array}{l}\text { Std. } \\
\text { Deviation }\end{array}$ & $\begin{array}{l}\text { Std. Error } \\
\text { Mean }\end{array}$ \\
\hline \multirow{2}{*}{$\begin{array}{l}\text { Post- } \\
\text { test }\end{array}$} & Control & 17 & 11,5294 & 8,14799 & 1,97618 \\
\hline & Experiment & 20 & 17,1000 & 7,71124 & 1,72428 \\
\hline
\end{tabular}

To figure out whether the differences in the pre-test and post-test scores of the two groups were statistically significant or not, the following $t$ test table (and the $p$ value therein) had to be checked.

Table 3. Results of the independent-samples t-test comparing pre-test and post-test scores of the groups

Levene's $\quad$ Test for
Equality
Variances

\begin{tabular}{|c|c|c|c|c|c|c|c|}
\hline $\mathrm{F}$ & Sig. & $\mathrm{t}$ & $\mathrm{df}$ & $\begin{array}{l}\text { Sig.(2- } \\
\text { tailed) }\end{array}$ & $\begin{array}{l}\text { Mean } \\
\text { Difference }\end{array}$ & $\begin{array}{l}\text { Std.Error } \\
\text { Difference }\end{array}$ & $\begin{array}{l}\text { 95\% Confidence Interval of } \\
\text { the Difference }\end{array}$ \\
\hline
\end{tabular}

\begin{tabular}{|c|c|c|c|c|c|c|c|c|c|}
\hline & & & & & & & & \multirow{2}{*}{ Lower } & \multirow[b]{2}{*}{ Upper } \\
\hline & & & & & & & & & \\
\hline & 1,656 & ,207 & 1,748 & 35 & ,089 & 2,47941 & 1,41854 &,- 40038 & 5,35920 \\
\hline Test & & & 1,707 & 29,300 & ,098 & 2,47941 & 1,45216 &,- 48928 & 5,44810 \\
\hline & ,001 & ,976 & $-2,134$ & 35 & ,040 & $-5,57059$ & 2,61067 & $-10,87052$ &,- 27066 \\
\hline Test & & & $-2,124$ & 33,355 & 041 & $-5,57059$ & 2,62268 & $-10,90431$ &,- 23687 \\
\hline
\end{tabular}

Table 3 depicts that there were no statistically significant differences in pre-test scores of the control and the experiment group $(t=1,748, p=, 08)$. This meant that the two groups did not differ significantly in terms of their vocabulary knowledge prior to the intervention. Results of the post-test indicated that after a semester of exposure to the digital game-based activities, the experimental group's post-test scores were significantly higher than those of the control group. This implies that the intervention had a significant positive effect on the vocabulary knowledge of $3^{\text {rd }}$ grade EFL learners.

\section{Discussions}

The goal of the study was to examine the effectiveness of digital games on the third-grade English vocabulary development and learning and to compare games with pen and paper practices. For this purpose, the research question asked whether using digital games has effect on English 
vocabulary learning. Results of the study indicated that after a semester of exposure to the digital game-based activities, the experimental class' post-test scores were significantly higher than those of the control group. An independent sample $t$-test suggested there was a statistically significant difference in test scores between the experimental and control groups of students. This finding is supported by Ratminingsih, Mahadewi, and Divayana (2018) who state that the digital games help students learn while playing and come across grammatical patterns in different context. Similarly, Saffarian and Gorjian (2012) explored the effect of computer-based digital games for vocabulary development among young children in their study. After a pre-test and a post-test administered, they conveyed that computer-based digital games facilitated students' learning performance. In Another study supporting the findings, Lorenset and Tumolo (2019) investigated the use of the digital game The Sims using a pre-test and a post-test. Results indicated The Sims as effective for vocabulary acquisition in EFL.

The effect of using a digital computer game and its role on promoting Iranian children 's vocabulary learning was investigated by Aghlara and Tamjid (2011). The results indicated that the mean score of the children in the experimental group was significantly higher than those in the control group, indicating the positive effect of using digital games in teaching English vocabulary to children. Yip and Kwan (2006) have shown that students prefer learning that is supported by digital educational games rather than traditional activity-based lessons. According to their study, students who were provided with an electronic environment and games became more successful in learning new words compared to those who learned the same vocabulary through activity-based lessons.

\section{Conclusions}

Based on the results it can be concluded that the use of digital games in teaching English vocabulary to young learners was much more successful than the use of traditional methods. Digital tools are indispensable parts of most children's lives and using these tools in school could motivate children to enjoy classes more.

Digital games have replaced traditional games in the technology age and schools should keep up with the requisite of the age. For language learning, there are many methods to motivate and entertain young learners. However, games, especially digital ones, are up-to-date and more meaningful to those learners.

\section{Authors note:}

Esin Hazar is an assistant professor at Educational Sciences Department. She has studies on curriculum, instruction and information, media and technology skills. Digital game addiction and teaching English as a foreign language are her areas of interest. She lectures on curriculum development, scientific research methodologies.

\section{References}

Aghlara, L., \& Tamjid, N.H. (2011). The effect of digital games on Iranian children's vocabulary retention in foreign language acquisition. Procedia-Social and Behavioral Sciences, 29, 552-560.

Ashraf, H., Motlagh, F. G., \& Salami, M. (2014). The impact of online games on learning English vocabulary by Iranian (low-intermediate) EFL learners. ProcediaSocial and Behavioral Sciences, 98, 286-291.

Bakhsh, S. A. (2016). Using Games as a Tool in Teaching Vocabulary to Young Learners. English language teaching, 9(7), 120-128.

Calvo-Ferrer, J. R. (2017). Educational games as standalone learning tools and their motivational effect on $\mathrm{L}$ 2 vocabulary acquisition and perceived learning gains. British Journal of Educational Technology, 48(2), 264-278.

Çetin, E. (2013). Tanımlar ve temel kavramlar. Eğitsel Dijital Oyunlar: Kuram, Tasartm ve Uygulama, 2-18.

Ratminingsih, N. M., Mahadewi, L. P. P., \& Divayana, D. G. H. (2018). ICT-based interactive game in TEYL: Teachers' perception, students' motivation, and achievement. International Journal of Emerging Technologies in Learning (iJET), 13(09), 190-203.

Hong, J. C., Cheng, C. L., Hwang, M. Y., Lee, C. K., \& Chang, H. Y. (2009). Assessing the educational values of digital games. Journal of Computer Assisted Learning, 25(5), 423-437.

Ilomäki, L., \& Kankaanranta, M. (2009). The information and communication technology (ICT) competence of the young. In Handbook of research on new media literacy at the K-12 level: Issues and challenges (pp. 101-118). IGI Global.

Liu, G. Z., Wu, N. W., \& Chen, Y. W. (2013). Identifying emerging trends for implementing learning technology in special education: A state-of-the-art review of selected articles published in 2008-2012. Research in developmental disabilities, 34(10), 3618-3628.

Lorenset, C., \& Tumolo, C. H. (2019). Vocabulary Acquisition in English as a Foreign Language: Digital Gameplaying The Sims. Revista Linguagem \& Ensino, 22(4), 1002-1019

Loucky, J. P. (1998). Suggestions for Improving ESL/EFL Vocabulary Instruction. Seinan Jogakuin Junior College Bulletin, 45, 1-12.

Mayer, R. E. (2015). On the need for research evidence to guide the design of computer games for learning. Educational psychologist, 50(4), 349-353.

McGonigal, J. (2013). Reality is broken: Why games make us better and how they can change the world. New York, NY: Penguin. 
Mukoroli, J. (2011). Effective vocabulary teaching strategies for the English for academic purposes ESL classroom. MA TESOL Collection. Paper 501. Retrieved from http://digitalcollections.sit.edu/cgi/viewcontent.cgi?art icle $=1503 \&$ context $=$ ipp_collection .

Nation, I. S. (2013). Learning vocabulary in another language Google eBook. Cambridge University Press.

Nunan, D. (1991). Methods in second language classroomoriented research: A critical review. Studies in second language acquisition, 249-274.

Patahuddin, P., Syawal, S., \& Bin-Tahir, S. Z. (2017). Investigating Indonesian EFL learners' learning and acquiring English vocabulary. International Journal of English Linguistics, 7(4), 128.

Peterson, M. (2013). Computer games and language learning. New York: Palgrave Macmillan.

Prensky, M. (2001). Fun, play and games: What makes games engaging. Digital game-based learning, 5(1), 531.

Ratminingsih, N. M., Mahadewi, L. P. P., \& Divayana, D. G. H. (2018). ICT-Based Interactive Game in TEYL: Teachers' Perception, Students' Motivation, and Achievement. International Journal of Emerging Technologies in Learning (iJET), 13(09), 190-203.

Reinhardt, J. S., \& Sykes, J. M. (2014). Digital game and play activity in L2 teaching and learning. Language Learning and Technology, 18(2), 2-8.

Saffarian, R., \& Gorjian, B. (2012). Effect of computerbased video games for vocabulary acquisition among young children: An experimental study. Journal of Comparative Literature and Culture, 1(3), 44-48.

Shyamlee, S. D., \& Phil, M. (2012, March). Use of technology in English language teaching and learning:
An analysis. In International Conference on Language, Medias and Culture (Vol. 33, No. 1, pp. 150-156).

Stewart, J., Bleumers, L., Van Looy, J., Mariën, I., All, A., Schurmans, D., ... \& Misuraca, G. (2013). The potential of digital games for empowerment and social inclusion of groups at risk of social and economic exclusion: evidence and opportunity for policy. Joint Research Centre, European Commission.

Sundqvist, P., \& Sylvén, L. K. (2014). Language-related computer use: Focus on young L2 English learners in Sweden. ReCALL, 26(1), 3-20.

Taghizadeh, M., Vaezi, S., \& Ravan, M. (2017). Digital Games, Songs and Flashcards and their Effects on Vocabulary Knowledge of Iranian Preschoolers. Studies, 5(4), 156-171.

Takeuchi, L. M., \& Vaala, S. (2014). Level up Learning: A National Survey on Teaching with Digital Games. In Joan Ganz Cooney Center at Sesame Workshop. Joan Ganz Cooney Center at Sesame Workshop. 1900 Broadway, New York, NY 10023.

Thomas, M. (2012). Contextualizing digital game-based language learning: Transformational paradigm shift or business as usual?. In Digital games in language learning and teaching (pp. 11-31). Palgrave Macmillan, London.

Vasileiadou, I., \& Makrina, Z. (2017). Using Online Computer Games in the ELT Classroom: A Case Study. English Language Teaching, 10(12), 134-150.

Wood, J. (2001). Can software support children's vocabulary development?. Language Learning \& Technology, 5(1), 166-201.

Yudintseva, A. (2015). Game-enhanced second language vocabulary acquisition strategies: A systematic review. Open Journal of Social Sciences, 3(10), 101. 